\title{
Effect of Vitamin C on Experimental Inoculation with Salmonella enteritidis in Broiler Chickens with Reference to Haemato-Biochemical Profile
}

\author{
Sanak Sharma*, Shagufta Azmi, Sankalp Sharma, Shafiqur Rahman and \\ Nawab Nashiruddullah
}
Division of veterinary pathology, Faculty of veterinary sciences and Animal husbandry, Sher- e-Kashmir University of Agricultural sciences and technology of Jammu, India

*Corresponding author

\section{A B S T R A C T}

\section{Keywords \\ Salmonella enteritidis, Vitamin C, Haemato- biochemical, Broiler chickens \\ Article Info \\ Accepted: \\ 04 August 2018 \\ Available Online: \\ 10 September 2018}

The present study was conducted to evaluate the haemato- biochemical alterations caused by Salmonellosis and to evaluate the ameliorative effect of Vitamin $\mathrm{C}$ in broiler chickens. The study reveals that the deleterious effect of Salmonella enteritidis was suppressed by Vitamin C significantly.

\section{Introduction}

Poultry meat and eggs are a leading source of animal protein for human consumption in many countries. Owing to the implementation of greater numbers of monitoring and testing programmes in the poultry industry, isolation of Salmonella is reported more often from poultry and poultry products than any other animal source (Gast, 2003). Among the different diseases occurring in poultry, incidence of diseases caused by the genus Salmonella are the most common, causing serious losses to the poultry industry in terms of mortality, reduced growth and loss of egg production. The diseases caused by
Salmonella have got zoonotic importance (Lax et al., 1995). Poultry flocks are reservoirs of Salmonella enteritidis, whose incidence in the human population has increased considerably since the beginning of the 1990 (Lahuerta et al., 2011). The Salmonella enteritidis was prevalent in the R.S. Pura region which was isolated from the poultry by us and hence this study was done.

\section{Materials and Methods}

In the present study a total of 72 -day old broiler chicks were randomly divided into four groups viz. group I, II, III and IV with 18 birds in each group. Group I chicks were 
served as control. Group II chicks were challenged orally with $2 \times 10^{8}$ organisms of Salmonella enteritidis. Group III chicks were challenged orally with $2 \times 10^{8}$ organisms of Salmonella enteritidis and vitamin $\mathrm{C}$ mixed in water@200 ppm. Group IV birds were administered vitamin C @ 200 ppm.

Blood samples (3-4ml) were collected from six birds of each group at 7,14 and 28 DPI (Day post infection). The blood for hematological studies was collected in vials containing ethylene diaminetetra-acetic acid (EDTA) @ 2mg/ml of blood as an anticoagulant. The haemoglobin concentration $(\mathrm{Hb})$, Packed Cell Volume (PCV), Total erythrocyte count (TEC), Total leukocyte count (TLC) and differential leukocyte count (DLC) were done as per standard methods described by Schalm et al., (1975).

Erythrocytic indices- Mean Corpuscular Volume (MCV), Mean Corpuscular Haemoglobin (MCH), Mean Corpuscular Haemoglobin Concentration (MCHC) were calculated as per the formulae described by Schalm et al., (1975).

For biochemical studies, 3-4ml blood was collected separately from six birds of each group in dry clean and sterilized test tubes without the addition of anticoagulant at intervals 7, 14 and 28 DPI (Day Post Infection) and allowed to clot at room temperature. Serum was separated and preserved at $-20^{\circ} \mathrm{C}$ till analysed for estimation of various parameters such as total serum protein (Biuret method), albumin (BCG dye binding method), Aspartate aminotransferase (AST) and Alanine aminotransferase (ALT) (DNPH colorimetric method) using standard kits from Span Diagnostic Ltd. The globulins were calculated by subtracting the values of albumin from total serum proteins. The A: G ratio was calculated by dividing albumin values by globulin values.

\section{Results and Discussion}

The results of the haemato-biochemical study are presented in Table 1,2 and 3.

Estimation of $\mathrm{Hb}, \mathrm{PCV}$ and TEC revealed that there was significant decrease in $\mathrm{Hb}, \mathrm{PCV}$ and TEC in group II birds as compared to control group birds from $1^{\text {st }}$ week PI (Post Infection) up to the last observation. These results correspond with earlier findings in fowl typhoid (Buxton, 1960; Assoku and Penhale, 1970; Rusov and Dukic, 1980; Kokosharov and Todorova, 1987; Mdgela et al., 2002) and in different Salmonella serotypes infections (Bierer et al., 1965; Sapre and Mehta, 1970).

Galvin (1978) reported that birds suffering from infectious diseases seem to develop anaemia more easily than domestic animals. According to Assoku and Penhale (1970), decreased haematological values were due to effect of endotoxin of Salmonella which immunologically modify the erythrocytes and thereby causing them to be eliminated from the circulation rather than depression of the haemopoietic activity.

The group III birds showed significant increase in haemoglobin as compared to group II birds at $4^{\text {th }}$ week PI in our study. The increase in the values of PCV and hemoglobin of birds could be attributed to the effect of Vitamin $\mathrm{C}$ in protecting the membrane integrity of the erythrocytes as earlier reported (Candan et al., 2002; Adenkola et al., 2010). Besides, Vitamin $\mathrm{C}$ has also been attributed to increase in haemoglobin concentration because of increased absorption of iron from the digestive tract (Harper et al., 1979).

\section{Erythrocytic indices (MCV, MCH, MCHC)}

Studies on the mean corpuscular volume revealed that there was significant increase in MCV values in the group II than control group 
from $1^{\text {st }}$ week PI till the end of the study. MCV values of group I and group IV did not differ significantly throughout the entire study. The MCH values of infected groups did not differ from each other throughout the experimental study. Studies on the mean corpuscular haemoglobin concentration (MCHC) revealed no significant difference between group II and control birds. This indicates that the anemia encountered in this study was of macrocytic normochromic type. The results of present study correspond with Buxton (1960); Assoku et al., (1970); Allan and Duffs (1971); Smith et al., (1977) and Kokosharov and Todorova (1987) in Salmonella Gallinarum infection in chicken. According to Assoku et al., (1970) anaemia developed was due to extravascular destruction of erythrocytes. Allan and Duffs (1971) suggested the possible role of cytophilic antibodies in the destruction of altered erythrocytes. In present study also severe haemorrhages throughout the intestinal tract and other visceral organs was observed during gross pathological study. The group III birds did not show any significant change between group II birds in the value of MCV, $\mathrm{MCH}$ and MCHC in our study; Tuleun et al., (2011) also reported in Japanese quails. Similarly, Usman et al., (2008) observed no significant difference in $\mathrm{RBC}, \mathrm{Hb}, \mathrm{PCV}$, $\mathrm{MCV}, \mathrm{MCHC}$ and white blood cell count in Japanese quails.

\section{Total Leukocyte Count (TLC)}

Enumeration of total leukocyte counts revealed increase in the group II birds as compared with control. These findings are in accordance with the observations of Rao et al., (1952) in fowl typhoid, Sapre and Mehta (1970) in different Salmonella infections, Assoku and Penhale (1970); Rusov and Dukic (1980); Miyamoto et al., (1998) in chicken and turkey poults infected with Salmonella Enteritidis, Maxwell and Robertson (1998) in chickens infected with various types of Salmonella serotypes, Saini (1999) in chickens infected with Salmonella Enteritidis and Kokosharov (2002) in chicken infected with Salmonella Gallinarum. Leukocytosis is mainly encountered in acute and chronic inflammatory lesions and massive tissue necrosis (Coles, 1986). Leukocytosis has been attributed to bone marrow hyperplasia by Assoku and Penhale (1970). In present study also massive tissue necrosis occured as was observed during pathological study. The group III birds showed slight increase in the total leukocyte count when compared with group II birds in our study. This might be due to that ascorbic acid role in the synthesis of White Blood Cells especially phagocytes and heterophils which enhance immunity in broiler chickens (Null, 2001).

A study on the differential leukocyte count revealed that leukocytosis in the group II chickens was due to increase in the number of heterophils. A reduction in the percentage of lymphocytes in the differential leukocyte count was observed. Heterophils and monocytes increased significantly in the group II. Similar haematological changes had been reported in birds infected with Salmonella typhimurium (Sapre and Mehta, 1970), with Salmonella Gallinarum (Allan and Duffus, 1971), Salmonella Enteritidis (Miyamoto et al., 1998; Saini, 1999). The occurrence of leukocytosis has been attributed to bone marrow hyperplasia and extra medullary erythropoiesis in the spleen and liver (Assoku and Penhale, 1970). According to Maxwell and Robertson (1998), heterophils accounted for more than $80 \%$ increase in TLC in early stages of paratyphoid infection and played an important role in phagocytosis organisms in the absence of antibodies, organ invasion and subsequent pathogenesis. Heterophilia may be attributed to acute and chronic inflammatory diseases (Coles, 1986) and degenerative changes in the internal organs. 
Table.1 Mean values of haematological parameters in birds of different Groups at various intervals

\begin{tabular}{|c|c|c|c|c|c|}
\hline Parameter & $\begin{array}{l}\text { Week } \\
\text { PI* }\end{array}$ & Group I & Group II & Group III & Group IV \\
\hline \multirow[t]{3}{*}{$\mathrm{Hb}(\mathrm{g} / \mathrm{dl})$} & $1^{\mathrm{st}}$ & $7.35 \pm 0.03^{\mathrm{aA}}$ & $6.56 \pm 0.14^{\mathrm{bA}}$ & $6.57 \pm 0.06^{\mathrm{bA}}$ & $7.38 \pm 0.04^{\mathrm{aA}}$ \\
\hline & $2^{\text {nd }}$ & $8.26 \pm 0.06^{\mathrm{aB}}$ & $6.13 \pm 0.07^{\mathrm{bA}}$ & $6.29 \pm 0.17^{\mathrm{bA}}$ & $8.30 \pm 0.03^{\mathrm{aB}}$ \\
\hline & $4^{\text {th }}$ & $9.45 \pm 0.08^{\mathrm{aC}}$ & $5.97 \pm 0.07^{\mathrm{cB}}$ & $6.19 \pm 0.06^{\mathrm{bA}}$ & $9.47 \pm 0.17^{\mathrm{aB}}$ \\
\hline \multirow[t]{3}{*}{ PCV (\%) } & $1^{\mathrm{st}}$ & $22.05 \pm 0.10^{\mathrm{aA}}$ & $19.68 \pm 0.16^{\mathrm{bA}}$ & $19.71 \pm 0.18^{\mathrm{bA}}$ & $22.14 \pm 0.12^{\mathrm{aA}}$ \\
\hline & $2^{\text {nd }}$ & $24.78 \pm 0.18^{\mathrm{aB}}$ & $18.39 \pm 0.21^{\mathrm{bB}}$ & $18.87 \pm 0.16^{\mathrm{bB}}$ & $24.90 \pm 0.16^{\mathrm{aB}}$ \\
\hline & $4^{\text {th }}$ & $28.35 \pm 0.25^{\mathrm{aC}}$ & $17.91 \pm 0.18^{\mathrm{cC}}$ & $18.57 \pm 0.14^{\mathrm{bB}}$ & $28.47 \pm 0.21^{\mathrm{aC}}$ \\
\hline \multirow[t]{3}{*}{ TEC (millions/ $\mu$ ) } & $1^{\text {st }}$ & $3.23 \pm 0.17^{\mathrm{aA}}$ & $2.40 \pm 0.14^{\mathrm{bA}}$ & $2.42 \pm 0.16^{\mathrm{bA}}$ & $3.25 \pm 0.09^{\mathrm{aA}}$ \\
\hline & $2^{\text {nd }}$ & $3.25 \pm 0.14^{\mathrm{aA}}$ & $2.21 \pm 0.14^{\mathrm{bA}}$ & $2.23 \pm 0.09^{\mathrm{bA}}$ & $3.26 \pm 0.14^{\mathrm{aA}}$ \\
\hline & $4^{\text {th }}$ & $3.31 \pm 0.40^{\mathrm{aB}}$ & $1.98 \pm 0.10^{\mathrm{cB}}$ & $2.15 \pm 0.19^{\mathrm{bB}}$ & $3.31 \pm 0.17^{\mathrm{aB}}$ \\
\hline \multirow{3}{*}{$\begin{array}{c}\text { TLC } \\
\text { (thousands/ } / \mu \mathrm{l} \text { ) }\end{array}$} & $1^{\mathrm{st}}$ & $22.43 \pm 0.14^{\mathrm{aA}}$ & $33.10 \pm 0.92^{\mathrm{aA}}$ & $33.15 \pm 0.90^{\mathrm{aA}}$ & $22.48 \pm 0.14^{\mathrm{aA}}$ \\
\hline & $2^{\text {nd }}$ & $23.84 \pm 0.14^{\mathrm{bA}}$ & $41.90 \pm 0.37^{\mathrm{aB}}$ & $41.91 \pm 0.55^{\mathrm{aB}}$ & $23.92 \pm 0.17^{\mathrm{bA}}$ \\
\hline & $4^{\text {th }}$ & $29.13 \pm 0.23^{\mathrm{bB}}$ & $46.83 \pm 0.53^{\mathrm{aC}}$ & $47.00 \pm 0.89^{\mathrm{aC}}$ & $29.36 \pm 0.29^{\mathrm{bB}}$ \\
\hline \multirow[t]{3}{*}{$\overline{M C V}$ (fl) } & $1^{\text {st }}$ & $68.26 \pm 0.24^{\mathrm{bA}}$ & $8207 \pm 0.18^{\mathrm{aA}}$ & $81.44 \pm 0.96^{\mathrm{aA}}$ & $68.12 \pm 0.44^{\mathrm{bA}}$ \\
\hline & $2^{\text {nd }}$ & $76.24 \pm 0.33^{\mathrm{bB}}$ & $83.21 \pm 0.43^{\mathrm{aA}}$ & $82.67 \pm 0.19^{\mathrm{aA}}$ & $76.38 \pm 0.37^{\mathrm{bB}}$ \\
\hline & $4^{\text {th }}$ & $77.64 \pm 0.65^{\mathrm{bB}}$ & $86.37 \pm 0.46^{\mathrm{aB}}$ & $85.24 \pm 0.38^{\mathrm{aB}}$ & $77.69 \pm 0.66^{\mathrm{bB}}$ \\
\hline \multirow[t]{3}{*}{ MCH (pg) } & $1^{\mathrm{st}}$ & $22.75 \pm 0.51^{\mathrm{bA}}$ & $27.33 \pm 0.68^{\mathrm{aA}}$ & $27.14 \pm 0.24^{\mathrm{aA}}$ & $22.70 \pm 0.56^{\mathrm{bA}}$ \\
\hline & $2^{\text {nd }}$ & $25.41 \pm 0.66^{\mathrm{bB}}$ & $27.73 \pm 1.04^{\mathrm{aA}}$ & $28.20 \pm 0.45^{\mathrm{aB}}$ & $25.46 \pm 0.66^{\mathrm{bB}}$ \\
\hline & $4^{\text {th }}$ & $26.54 \pm 0.35^{\mathrm{bB}}$ & $30.46 \pm 0.18^{\mathrm{aB}}$ & $29.79 \pm 1.20^{\mathrm{aB}}$ & $26.56 \pm 0.92^{\mathrm{bB}}$ \\
\hline \multirow[t]{3}{*}{ MCHC (g\%) } & $1^{\mathrm{st}}$ & $29.69 \pm 0.45^{\mathrm{aA}}$ & $28.45 \pm 0.42^{\mathrm{aA}}$ & $28.47 \pm 0.66^{\mathrm{aA}}$ & $29.71 \pm 0.26^{\mathrm{aA}}$ \\
\hline & $2^{\text {nd }}$ & $29.86 \pm 0.73^{\mathrm{aA}}$ & $27.63 \pm 0.33^{\mathrm{aA}}$ & $27.69 \pm 0.13^{\mathrm{aA}}$ & $29.88 \pm 0.43^{\mathrm{aA}}$ \\
\hline & $4^{\text {th }}$ & $30.90 \pm 0.86^{\mathrm{aB}}$ & $26.43 \pm 0.75^{\mathrm{aB}}$ & $26.49 \pm 0.19^{\mathrm{aB}}$ & $30.91 \pm 0.88^{\mathrm{aB}}$ \\
\hline
\end{tabular}

*PI=Post Infection; Mean bearing at least one common superscript (a, b, c and A, B, C) did not differ significantly between groups and weeks $(\mathrm{P}<0.05)$, respectively.

Table.2 Mean values of DLC (\%) in birds of different groups at various intervals

\begin{tabular}{|c|c|c|c|c|c|}
\hline Cell type & $\begin{array}{c}\text { Weeks } \\
\text { PI** }\end{array}$ & Group I & Group II & Group III & Group IV \\
\hline \multirow[t]{3}{*}{ Heterophils (\%) } & $1^{\text {st }}$ & $28.33 \pm 1.03^{\mathrm{bA}}$ & $54.38 \pm 1.14^{\mathrm{aA}}$ & $53.19 \pm 1.20^{\mathrm{aA}}$ & $28.33 \pm 1.03^{\mathrm{bA}}$ \\
\hline & $2^{\text {nd }}$ & $29.32 \pm 0.42^{\mathrm{bA}}$ & $58.23 \pm 0.54^{\mathrm{aA}}$ & $59.00 \pm 0.54^{\mathrm{aA}}$ & $29.32 \pm 0.54^{\mathrm{bA}}$ \\
\hline & $4^{\text {th }}$ & $29.00 \pm 0.85^{\mathrm{cA}}$ & $50.17 \pm 1.45^{\mathrm{bA}}$ & $53.43 \pm 1.54^{\mathrm{aA}}$ & $30.00 \pm 1.54^{\mathrm{cA}}$ \\
\hline \multirow[t]{3}{*}{ Lymphocytes (\%) } & $1^{\text {st }}$ & $65.60 \pm 1.86^{\mathrm{aA}}$ & $41.33 \pm 0.86^{\mathrm{bA}}$ & $42.33 \pm 0.56^{\mathrm{bA}}$ & $65.60 \pm 0.56^{\mathrm{aA}}$ \\
\hline & $2^{\text {nd }}$ & $66.15 \pm 0.85^{\mathrm{aA}}$ & $33.11 \pm 0.33^{\mathrm{bB}}$ & $34.13 \pm 0.33^{\mathrm{bB}}$ & $66.15 \pm 1.21^{\mathrm{aA}}$ \\
\hline & $4^{\text {th }}$ & $66.25 \pm 0.85^{\mathrm{aA}}$ & $32.44 \pm 0.56^{\mathrm{cB}}$ & $34.34 \pm 0.33^{\mathrm{bB}}$ & $66.25 \pm 0.76^{\mathrm{aA}}$ \\
\hline \multirow[t]{3}{*}{ Monocytes (\%) } & $1^{\text {st }}$ & $3.48 \pm 0.33^{\mathrm{bA}}$ & $5.76 \pm 0.67^{\mathrm{aA}}$ & $5.27 \pm 0.56^{\mathrm{aA}}$ & $3.48 \pm 0.33^{\mathrm{bA}}$ \\
\hline & $2^{\text {nd }}$ & $3.78 \pm 1.34^{\mathrm{bA}}$ & $6.67 \pm 0.43^{\mathrm{aB}}$ & $6.38 \pm 1.04^{\mathrm{aB}}$ & $3.78 \pm 0.66^{\mathrm{bA}}$ \\
\hline & $4^{\text {th }}$ & $3.80 \pm 0.66^{\mathrm{bA}}$ & $7.33 \pm 0.66^{\mathrm{aB}}$ & $7.15 \pm 0.56^{\mathrm{aB}}$ & $3.80 \pm 0.33^{\mathrm{bA}}$ \\
\hline \multirow[t]{3}{*}{ Eosinophils (\%) } & $1^{\text {st }}$ & $1.00 \pm 0.36^{\mathrm{aA}}$ & $1.33 \pm 0.65^{\mathrm{aA}}$ & $1.33 \pm 0.33^{\mathrm{aA}}$ & $1.00 \pm 0.88^{\mathrm{aA}}$ \\
\hline & $2^{\text {nd }}$ & $1.25 \pm 0.45^{\mathrm{aA}}$ & $1.66 \pm 0.46^{\mathrm{aA}}$ & $1.33 \pm 0.67^{\mathrm{aA}}$ & $1.25 \pm 0.74^{\mathrm{aA}}$ \\
\hline & $4^{\text {th }}$ & $1.33 \pm 0.54^{\mathrm{aA}}$ & $2.00 \pm 0.33^{\mathrm{aA}}$ & $1.66 \pm 0.49^{\mathrm{aA}}$ & $1.33 \pm 0.66^{\mathrm{aA}}$ \\
\hline \multirow[t]{3}{*}{ Basophils (\%) } & $1^{\text {st }}$ & $0.30 \pm 0.19^{\mathrm{aA}}$ & $1.00 \pm 0.00^{\mathrm{aA}}$ & $1.00 \pm 0.34^{\mathrm{aA}}$ & $0.30 \pm 0.10^{\mathrm{aA}}$ \\
\hline & $2^{\text {nd }}$ & $0.44 \pm 0.27^{\mathrm{aA}}$ & $1.33 \pm 0.13^{\mathrm{aA}}$ & $1.00 \pm 0.66^{\mathrm{aA}}$ & $0.40 \pm 0.00^{\mathrm{aA}}$ \\
\hline & $4^{\text {th }}$ & $0.55 \pm 0.42^{\mathrm{aA}}$ & $1.76 \pm 0.52^{\mathrm{aA}}$ & $1.46 \pm 0.33^{\mathrm{aA}}$ & $0.55 \pm 0.12^{\mathrm{aA}}$ \\
\hline
\end{tabular}

*PI=Post Infection; Mean bearing at least one common superscript (a, b, c and A, B) did not differ significantly between groups and weeks $(\mathrm{P}<0.05)$, respectively. 
Table.3 Mean values of biochemical parameters in birds of different groups at various intervals

\begin{tabular}{|c|c|c|c|c|c|}
\hline Parameter & Week PI* & Group I & Group II & Group III & Group IV \\
\hline \multirow{3}{*}{$\begin{array}{l}\text { Total serum } \\
\text { protein (g/dl) }\end{array}$} & $1^{\mathrm{st}}$ & $3.95 \pm 0.01^{\mathrm{aA}}$ & $2.36 \pm 0.03^{\mathrm{bA}}$ & $2.36 \pm 0.02^{\mathrm{bA}}$ & $3.96 \pm 0.01^{\mathrm{aA}}$ \\
\hline & $2^{\text {nd }}$ & $4.02 \pm 0.02^{\mathrm{aA}}$ & $1.94 \pm 0.02^{\mathrm{bB}}$ & $1.95 \pm 0.01^{\mathrm{bB}}$ & $4.04 \pm 0.03^{\mathrm{aA}}$ \\
\hline & $4^{\text {th }}$ & $4.05 \pm 0.02^{\mathrm{aA}}$ & $1.90 \pm 0.01^{\mathrm{bB}}$ & $1.93 \pm 2.94^{\mathrm{bB}}$ & $4.08 \pm 0.02^{\mathrm{aA}}$ \\
\hline \multirow[t]{3}{*}{ Albumin (g/dl) } & $1^{\mathrm{st}}$ & $3.16 \pm 0.03^{\mathrm{aA}}$ & $2.46 \pm 0.02^{\mathrm{bA}}$ & $2.45 \pm 0.08^{\mathrm{bA}}$ & $3.17 \pm 0.03^{\mathrm{aA}}$ \\
\hline & $2^{\text {nd }}$ & $3.25 \pm 0.03^{\mathrm{aA}}$ & $2.05 \pm 0.04^{\mathrm{bA}}$ & $2.07 \pm 0.06^{\mathrm{bA}}$ & $3.26 \pm 0.02^{\mathrm{aA}}$ \\
\hline & $4^{\text {th }}$ & $3.28 \pm 0.03^{\mathrm{aA}}$ & $1.46 \pm 0.01^{\mathrm{bB}}$ & $1.49 \pm 0.04^{\mathrm{bB}}$ & $3.29 \pm 0.06^{\mathrm{aA}}$ \\
\hline \multirow[t]{3}{*}{ globulin (g/dl) } & $1^{\mathrm{st}}$ & $0.71 \pm 0.04^{\mathrm{bA}}$ & $0.96 \pm 0.04^{\mathrm{aA}}$ & $0.96 \pm 0.09^{\mathrm{aA}}$ & $0.72 \pm 0.03^{\mathrm{bA}}$ \\
\hline & $2^{\text {nd }}$ & $0.97 \pm 0.11^{\mathrm{bB}}$ & $1.24 \pm 0.13^{\mathrm{aB}}$ & $1.26 \pm 0.02^{\mathrm{aB}}$ & $0.98 \pm 0.03^{\mathrm{bB}}$ \\
\hline & $4^{\text {th }}$ & $1.12 \pm 0.02^{\mathrm{bB}}$ & $1.33 \pm 0.02^{\mathrm{aB}}$ & $1.35 \pm 0.02^{\mathrm{aB}}$ & $1.14 \pm 0.04^{\mathrm{bB}}$ \\
\hline \multirow[t]{3}{*}{ A:G ratio } & $1^{\mathrm{st}}$ & $4.45 \pm 0.43^{\mathrm{aA}}$ & $2.55 \pm 0.09^{\mathrm{bA}}$ & $2.55 \pm 0.28^{\mathrm{bA}}$ & $4.40 \pm 0.25^{\mathrm{aA}}$ \\
\hline & $2^{\text {nd }}$ & $3.35 \pm 0.33^{\mathrm{aA}}$ & $1.65 \pm 0.13^{\mathrm{bB}}$ & $1.64 \pm 0.08^{\mathrm{bB}}$ & $3.32 \pm 0.22^{\mathrm{aA}}$ \\
\hline & $4^{\text {th }}$ & $2.92 \pm 3.98^{\mathrm{aA}}$ & $1.09 \pm 0.01^{\mathrm{bB}}$ & $1.10 \pm 0.01^{\mathrm{bB}}$ & $2.88 \pm 0.29^{\mathrm{aA}}$ \\
\hline \multirow[t]{3}{*}{ AST (IU/I) } & $1^{\mathrm{st}}$ & $43.80 \pm 0.36^{\mathrm{bA}}$ & $67.66 \pm 0.22^{\mathrm{aA}}$ & $67.48 \pm 0.29^{\mathrm{aA}}$ & $42.63 \pm 0.44^{\mathrm{bA}}$ \\
\hline & $2^{\text {nd }}$ & $44.66 \pm 0.16^{\mathrm{bA}}$ & $119.70 \pm 0.48^{\mathrm{aB}}$ & $118.45 \pm 0.38^{\mathrm{aB}}$ & $44.35 \pm 0.41^{\mathrm{bA}}$ \\
\hline & $4^{\text {th }}$ & $45.51 \pm 0.18^{\mathrm{bA}}$ & $123.32 \pm 0.23^{\mathrm{aB}}$ & $121.51 \pm 0.17^{\mathrm{aB}}$ & $45.21 \pm 0.13^{\mathrm{bA}}$ \\
\hline \multirow[t]{3}{*}{ ALT (IU/I) } & $1^{\mathrm{st}}$ & $19.63 \pm 0.21^{\mathrm{bA}}$ & $49.26 \pm 0.23^{\mathrm{aA}}$ & $49.26 \pm 0.14^{\mathrm{aA}}$ & $19.63 \pm 0.20^{\mathrm{bA}}$ \\
\hline & $2^{\text {nd }}$ & $21.43 \pm 0.36^{\mathrm{bA}}$ & $76.65 \pm 0.29^{\mathrm{aB}}$ & $76.53 \pm 0.29^{\mathrm{aB}}$ & $21.42 \pm 0.37^{\mathrm{bA}}$ \\
\hline & $4^{\text {th }}$ & $23.67 \pm 0.30^{\mathrm{bA}}$ & $88.41 \pm 0.65^{\mathrm{aC}}$ & $87.24 \pm 0.15^{\mathrm{aC}}$ & $23.66 \pm 0.28^{\mathrm{bA}}$ \\
\hline
\end{tabular}

*PI=Post Infection; Mean bearing at least one common superscript (a, b and A, B, C) did not differ significantly between groups and weeks $(\mathrm{P}<0.05)$, respectively.

In the present study too, there was more increase in the number of heterophils in the early phase of infection. The group III birds showed increase in the heterophils and lymphocyte count when compared with group II birds in the present study. This might be due to that ascorbic acid role in the synthesis of White Blood Cells especially Phagocytes and Heterophils which enhance immunity in broiler chickens (Null, 2001). Ascorbic acid is required for Heterophil function and decreases circulating glucocorticoids, thus, plays a critical role in immune response. Lymphocytes secrete antibodies that bind to foreign microorganisms in body tissues and mediate their destruction (Britannica, 2013).

\section{Serum biochemistry}

Studies on the total serum proteins (TSP) and albumin concentration revealed that there was a significant decrease in group II than the control group. The results of present study correspond with the findings of Halsey (2003) in Salmonella typhimurium infection in chickens, Ganovska (1981); Kokoshorarov (2006) in Salmonella gallinarum infection in chicken, Gupta et al., (1999) in Salmonella Dublin infection in guinea-pigs. According to Blood et al., (1994), hypoproteinemia may be due to i) renal diseases which lead to protein loss, ii) liver damage which causes failure in the synthesis of plasma proteins and iii) congestive heart failure. In addition to these, hypoproteinemia may also occur due to malnutrition and malabsorption (Coles, 1986).

In the present study, there was decreased appetite and damage to liver and kidney tissue as was evident from pathological studies. In addition, Kokosharov (2000) observed that Salmonella strains produce certain enzymes as catalases which induce proteolysis. The group III birds showed increase in TSP and albumin concentration when compared with group II birds in the present study. These 
findings were also reported by Majekodunmi et al., (2013); Seyrek et al., (2004) in quails.

Studies on the globulin concentration revealed that there was increase in the groups II from $1^{\text {st }}$ week PI which continued up to $4^{\text {th }}$ week PI. Hyperglobulinemia is associated with chronic diseases and bacterial septicemia (Coles, 1986). Coles (1986) reported that infections produce marked increase in alpha globulins and these findings correspond with that of Ganovska (1981); Kokosharov (2006) in chicken infected with Salmonella Gallinarum Gupta et al., (1999) in guineapigs infected with Salmonella typhimurium. Globulin is a reactive protein and a plasma precursor with gamma globulins being stimulated by the presence of antigens and synthesized by plasma cells (Frandson and Spurgeon, 1992) and lymphocytes containing the antibodies known as immunoglobulins (Duke, 1993). Gamma-globulin is associated with immunity and resistance to diseases. The group III birds show non-significant change in globulin concentration as compared to group II birds. Studies on A: G ratio revealed that there was significant decrease in the infected groups than control group. The significant decrease in $A: G$ ratio as observed in this study was because of decrease in albumin concentration and increase in globulin concentration.

\section{Serum enzymes}

Studies on the aspartate aminotransferase or serum glutamate oxaloacetate transferase (SGOT) levels revealed that there was significant increase in all the infected groups from $7^{\text {th }}$ DPI which continued till last observation. These results correspond with the findings of Kokosharov and Goranov (1997) who observed that level of aspartate aminotransferase increased 4 days after infection with Salmonella Gallinarum. Serum AST increases in hepatic and renal damage as well as muscular dystrophy. Galvin (1980) reported that most common cause of elevated serum AST level in caged birds was hepatic disease. Corduk et al., (2007) stated that an increase in AST activity is an of progressive liver cell injury followed by an increased production of reactive oxygen species due to external factors such as heat, trauma, infection, toxin and exercise. According to Brenes et al., (2003) and Rajman et al., (2006), plasma AST is not so specific and sensitive to hepatocellular damage in birds as it is in mammals, but Denli et al., (2004) regarded the activity of AST in serum of birds a sensitive indicator of acute hepatic necrosis. In present study also marked damage to hepatic tissue, renal tissue and cardiac tissue was observed during gross and histopathological examination. The group III birds showed non-significant decrease in AST values as compared with group II birds. This may be due to hepatoprotective effect of Vitamin C. Studies on the serum ALT revealed significantly higher values in group II from $1^{\text {st }}$ week PI up to last observation. These results correspond with the findings of Kokosharov and Goranov (1997) who reported that level of serum ALT increased after 2 days of infection with Salmonella Gallinarum, Gupta et al., (1999) in guineapigs infected with $S$. Dublin. The most important cause for elevation of serum ALT in birds is liver damage. Halliwell (1981) reported elevations in serum ALT in chicken with hepatic injury. In present study, there was hepatic damage as was evident from pathological studies so increased level of these enzymes.

The group III birds showed non-significant decrease in ALT values as compared with group II birds. This may be due to hepatoprotective effect of Vitamin $\mathrm{C}$.

\section{References}

Adenkola, A.Y., Kaankuka, F.G., Ikyume, T. T., Ichaver, I. F. and Yaakugh, I. D. I. 2010. Ascorbic acid effect on 
erythrocyte osmotic fragility, haematological parameters and performance of weaned rabbits at the end of rainy season in Makurdi Nigeria. Animal Plant Science, 9 (1): 1077-1085.

Allan, D. and Duffus. W. P. H. 1971. The immunopathology in fowls (Gallus domesticus) of acute and subacute Salmonella gallinarum infection. Research Veterinary Science, 12: 140151.

Assoku, R. K., Penhale, W. P. and Buxton, A. 1970. Haematological changes in acute experimental Salmonella gallinarum infection in chickens. Journal of Compound Pathology, 80: 473-485.

Bierer, B. W. 1960. Effect of age factor on mortality in Salmonella typhimurium infection in turkey poults. Journal of American Veterinary Medicine Association, 137: 657-658.

Bierer, B.W., Thomas, J. B., Roebuck, D. E., Powell, H. S. and Eleazer, T. H. 1965.Haematocrit and sedimentation rate values as an aid in poultry disease diagnosis. Journal of American Veterinary Medicine Association, 143: 1096.

Blood, D. C., Radostitis, O. M., Gay, C. C., Arundel, C. H., Ikede, B. O., Mckenzie, R. A., Trembley, R. R. M. and Henderson, J. A. 1994.Veterinary Medicine. (ed. $8^{\text {th }}$ ). pp. 809-834. The English Language Book Society and Bailliere Tindall, Eastbourne.

Brenes, A., Viveros, A., Arija, I., Centeno, C., Pizzaro, M. and Bravo, C. 2003. The effect of citric acid and microbial phytase on mineral utilization in broiler chicks. Animal Feed Science and Technology, 110: 201-219.

Britannica, 2013. White blood cells. www.Britannica.com. 337728.

Buxton, A. 1960. Pathological changes in the blood of chickens infected with
Salmonella gallinarum. Journal of Compound Pathology, 70: 308-325.

Candan, F., Gultekin, F. and Candan, F. 2002. Effect of Vitamin $\mathrm{C}$ and Zinc on fragility and lipid peroxidation in Zincdeficient haemodialysis patent. Cell Biochemistry and Function, 20: 95-98.

Coles, E. H. 1986. Avian Clinical Pathology, $\left(\right.$ edn. $\left.4^{\text {th }}\right)$. W. B. Saunders Company, Philadelphia. pp. 279-301.

Corduk, M., Ceylan, N. and Ildiz, F. 2007. Effects of dietary energy density and Lcarnitine supplementation on growth performance, carcass traits and blood parameters of broiler chickens. South African Journal of Animal Science, 37(2): 34-38.

Denli, M., Okan, F. and Doran, F. 2004. Effect of conjugated linoleic acid (CLA) on the performance and serum variables of broiler chickens intoxicated with aflatoxin $\mathrm{B}_{1}$. South African Journal of Animal Science, 34(1): 46-50.

Duke, G. E. 1993. Avian digestion. In; Dukes Physiology of Domestic animals (ed. $\left.11^{\text {th }}\right)$. Swenson, M. J, and Reece, W.O. Cornell University Press, New York.

Frandson, R. D and Spurgeon, T. L. 1992. Anatomy and Physiology of farm animals. (ed. $5^{\text {th }}$ ). Lippincott Williams and Wilkins, USA, 227-247., 484-512.

Galvin, C. E. 1978. Approach to the anaemic patient. California Veterinary Medical Association, 2: 12.

Galvin, C. E. 1980. Laboratory diagnostic aids in pet bird practice. In: Proceedings in American Animal Science Association, South Bend, USA.

Ganovska, M. 1981. Effect of dietary proteins on blood proteins of fowls infected with Salmonella gallinarum Veterinarno Meditsinski Nauki, 18: 64-72.

Gast, R. 2003. Salmonella infections, (ed. $\left.11^{\text {th }}\right)$. Diseases in Poultry. 587-597.

Gupta, V., Ray, J. and Sharma, M. 1999. Microbiological resistance pattern of 
Shigella and non-typhi Salmonella isolated from patients with diarrhoea. Indian Journal of Medical Research, 19 (9): 49-51.

Halliwell, W. H. 1981. Serum chemistry profiles in the health and disease of birds of prey. In: Cooper, J. E and Greenwood, A. G. (ed. $4^{\text {th }}$ ). Recent Advances in the Study of Raptor diseases. Chiron Publications Ltd. West Yorkshire, England.135-139.

Halsey, T. L. 2003. Salmonella typhimurium infection in broilers and its effects on gastrointestinal health and performance. M. Sc (Agric.) thesis, University of Pretoria, South Africa.

Harper, H. A., Rodwell., Mayer, V. W. and Peter, A. 1979. Review of physiological chemistry. (ed. 17 ${ }^{\text {th }}$ ), London. 159-160.

Kokosharov, T and Goranov, H. 1997. Enzyme activities and lipid levels in the serum of poultry with experimental acute Salmonella gallinarum infection. Veterinarski Archive, 67: 53-58.

Kokosharov, T. 2000. Study upon the production of several enzymes from Salmonella gallinarum strains. Bulgarian Journal of Veterinary Medicine, 3: 179-184.

Kokosharov, T. 2002. Clinical and haematological effects of Salmonella gallinarum endotoxin in cockerels. Veterinary Archive, 72: 269-276.

Kokosharov, T. 2006. Changes in the protein profile in birds with experimental acute fowl typhoid. Bulgarian Journal of Veterinary Medicine, 9 (3): 189-192.

Kokosharov, T. and Todorova, T. 1987. Changes in the iron content, erythrocyte and haemoglobin in the blood of poultry with acute experimental fowl typhoid. Veterinarno Meditsinski Nauki, 21: 1826.

Lahuerta, A., Westrell, T., Takkinen, J., Boelaert, F., Rizzi, V., Helwigh, B., Borck, B., Korsgaard, H., Ammon, A. and Makela, P. 2011. Zoonoses in the European Union: Origin, distribution and dynamics. Euro Surveillance, 16 (13): 19832

Lax, A. J., Barrow, P. A., Jonrs, P.W. and Wallis, J. S. 1995. Current perspectives in Salmonellosis. Brazialian Veterinary Journal, 151: 351-377.

Majekodunmi, B. C., Sokunbi, O. A., Ogunwole, O. A. and Adebiyi, O. A. 2013. Influence of electrolytes and ascorbic acid supplementation on serum and erythrocytic indices of broiler chickens reared in a hot environment. African Journal of Agricultural Research, 8 (8): 701-706.

Maxwell, M. H. and Robertson, G. W. 1998. The avian heterophil leukocytes: a review. World's Poultry Science Journal, 54: 155-178.

Mdgela, R. H., Msoffe, P. L. M., Waihenya, R. W., Kasanga, J. C., Mtambo, M. M. A., Minga, U. M. and Olsen, J. E. 2002. Comparative pathogenesis of experimental infections with Salmonella gallinarum in local and commercial chickens. Tropical Animal Health Production, 34: 195-204.

Miyamoto, T., Horie, T., Fukata, T., Sasai, K. and Baba, E. 1998. Changes in microflora of the cloaca and oviduct of hens after intracloacal or intravaginal inoculation with Salmonella enteritidis. Avian Diseases, 42: 536-544.

Null. G. 2001. The antioxidant VitaminVitamin C, in: www. Vitaminc foundaion.org, 485-490.

Rajman, M., Jurani, M., Lamosova, D., Macajova, M., Sedlackova, M., Kostal, L., Jezova, D. and Vyboh, P. 2006. The effects of feed restriction on plasma biochemistry in growing meat type chickens (Gallus gallus). Comparative Biochemistry and Physiology, 145: 363371.

Rao, S. B. V., Narayan, S., Ramani, D. R. and 
Das, J. 1952. Avian Salmonellosis: Studies on Salmonella gallinarum. Indian Journal of veterinary Science, 12: 199-208.

Rusov, C. and Dukic, B. 1980. Use of haematology and bone marrow investigation for the diagnosis of acute Salmonellosis in fowls. Veterinary Yugoslavia, 29: 289-292.

Saini, S. K. 1999. Studies on the pathology and pathogenesis of Salmonella enteritidis infection in vaccinated and unvaccinated quail. M. V. Sc. Thesis, CCS Agricultural University, Hisar, Haryana.

Sapre, V. A. and Mehta, M. L. 1970. Hematological changes in Salmonella infections in poultry. Indian Journal of Animal Science, 40: 456-467.

Schalm, O. W., Jain, N. C. and Carroll, E. J. 1975. Veterinary Haematology. Lea and Febiger, Philadelphia.

Seyrek, K., Yenisey, C., Serter, M., Karginkiral, F., Ulutas, P.A. and Bardakcioglu, H. E. 2004. Effects of dietary Vitamin C supplementation on some serum biochemical parameters of laying Japanese quails exposed to heat stress. Revue de Medicine Veterinaire, 155 (6): 339-342.

Smith, I. M., Hill, R. and Licence, S. T. 1977. Enhancement of survival in acute experimental fowl typhoid in chicks by administration of iron dextran. Research Veterinary Science, 23: 263-268.

Tuleun, C. D., Adenkola, A. Y. and Afele, Tss. 2011. Effect of dietary ascorbic acid supplementation on the performance of Japanese (Coturnix coturnix japonica) quails in a tropical environment. Journal of Animal and Plant Sciences, 10 (2): 1268- 1275.

Usman, B. A., Mani, A. U. and Muyiwa, O.B. 2008. Effects of dietary treatments of ascorbic acid on the blood parameters, egg production and quality in quail (Coturnix coturnix japonica) subjected to heat stress. International Journal of Poultry Science, 7 (4): 344- 349.

\section{How to cite this article:}

Sanak Sharma, Shagufta Azmi, Sankalp Sharma, Shafiqur Rahman and Nawab Nashiruddullah. 2018. Effect of Vitamin C on Experimental Inoculation with Salmonella enteritidis in Broiler Chickens with Reference to Haemato-Biochemical Profile. Int.J.Curr.Microbiol.App.Sci. 7(09): 88-96. doi: https://doi.org/10.20546/ijcmas.2018.709.012 